\title{
How is the Awareness of Javanese Language Phonology of Elementary School Teacher Candidates?: Descriptive Qualitative Study
}

\author{
Endang Sri Maruti, Universitas Negeri Surabaya, Universitas PGRI Madiun, endang.19011@unesa.mhs.ac.id \\ Bambang Yulianto, Universitas Negeri Surabaya \\ Suhartono, Universitas Negeri Surabaya \\ Nur Samsiyah, Universitas PGRI Madiun \\ *Corresponding Author
}

\begin{abstract}
Introduction: language awareness needs to be developed to ensure that children can have it. In this process, each child must have different views in terms of developing language awareness. This research aimed to investigate the phonological awareness of Javanese language in Primary Teacher Education students who are also candidates for Javanese language teachers at the elementary school level. This is important considering that students' language skills are highly dependent on the ability of teachers at the initial level of learning, namely at the elementary school level. Phonological awareness greatly affects students' reading and writing skills. Especially in Javanese language where there are words that are well written and pronounced differently. For this reason, it is necessary to know how far the level of awareness of Javanese phonology in elementary school teacher candidates. Method: This research was a descriptive qualitative. The data were collected through observation and documentation in the form of student assignments regarding the skills of writing Javanese words, syllables, onset, rhythm, and phonemics, then analyzed constructively. Results: The study showed that the level of phonological awareness of Javanese language teacher candidates for elementary school was still low. Lots of mistakes in writing words. Conclusion: Javanese language teacher candidates have low awareness of Javanese language phonology, so it is necessary to increase mastery of other language materials, and it can be ensured that it also has an effect on the learning outcomes of Javanese language learning for elementary school students.
\end{abstract}

Keywords: Phonological Awareness, Phonemic Awareness, Ortho-Phonological Confusion

Received: 08.12.2020 Accepted: 20.01.2021 $\quad$ Published: 04.02.2021

\section{INTRODUCTION}

Language awareness is a mental quality that enables people to gain insight and attention in terms of production language and how it works ${ }^{1}$. Mental conditions in language are needed because emotional, one of which requires self-esteem in determining the mental quality of language, self-esteem and selfawareness are mutually contributing parts, self-esteem itself is an evaluation of self-assessment ${ }^{2,3}$. During the process of language acquisition as well as language learning, language awareness needs to be developed to ensure that children can have it. In this process, each child must have different views in terms of developing language awareness. Other research has also emphasized the need for a pedagogical approach that aims to help students in developing language awareness ${ }^{4}$.

Language awareness, when considered as an approach in the language teaching and learning process, supports the understanding that rejects deductive grammar teaching, namely the transfer of knowledge and rules about language to students as it is. Language awareness is not taught directly by the teacher or textbook but is developed intuitively and internally by the learner gradually. Also, language awareness contributes to the training of prudent, positive, and curious students through efforts to discover and express language during language use. Conscious language use is the most important indicator of language attitudes ${ }^{4,5}$. Likewise in Javanese, conscious use of Javanese is a manifestation of a positive language attitude. Language attitude awakened increase respect and towards the level of preservation of language and Javanese culture ${ }^{6}$.

Based on expert opinion above, it can be concluded that the awareness of Javanese language is defined as specific knowledge of a person about Javanese language, perceptual awareness, and sensitivity to the learning and use of Javanese language in general, as well as conscious attention to the relationship between culture and language. The types of language awareness include phonological awareness, 
morphological awareness, syntactic awareness, and semantic awareness. In this paper, it is discussed only at the level of phonological awareness, especially for teacher candidates in elementary school. As has been stated in other studies that phonological awareness is one of the best early indicators to measure children's reading skills, in this case, kids with aged elementary school low grade?

One aspect of children's language development that is important to pay attention in the early learning of elementary school is the learning process towards reading and writing skills. One of the determinants of success in reading and writing skills is the awareness of phonology in children. Other studies have added that phonological awareness is the sound system of a language, including the use and combination of sounds. In other words, phonological awareness is a person's quickness to the sound structure of a language. This requires a person's ability to be able to shift attention as quickly as possible from the structure of the sound into spoken and written language. Moreover, in the sound structure of Javanese language where there are "jejeg"and oblique characters which are different in terms of writing and pronunciation ${ }^{8}$.

Phonological awareness in the context of learning is the ability to detect and manipulate sound structures ${ }^{9}$. The development of sound structures in phonological awareness is sequential from the largest sound unit to the smallest unit, namely words, syllables, onset-rime, and sounds ${ }^{10}$. This is in line with what was stated by other studies showing that the initial development of phonological awareness was syllables, then rhyme and phoneme awareness. So, it can be underlined that the development of children's phonological awareness follows word awareness, syllable awareness, onset awareness (initial sound) \& rime (final sound), and sound awareness ${ }^{11}$.

Based on the opinion of the experts above, it can be concluded that the phonological awareness of the Javanese language is fast and responsive of a person to be able to understand the relationship between Latin letters and Javanese letters with sounds spoken. From that understanding, the role of Javanese language teachers in elementary schools during the learning process is very large. Class teachers who are also Javanese language teachers in elementary schools are an important key in the success of students to have phonological awareness which also greatly influences the level of reading and writing skills in Javanese, both Latin and Javanese script. For this reason, the level of phonological awareness of prospective elementary school teachers needs to be investigated. This is important considering that prospective teachers in elementary school will also become Javanese language teachers in the future and to assist stakeholders in making educational policies, especially in learning Javanese language in elementary schools.

Research on language awareness, especially phonological awareness has been done a lot, but to the knowledge of the researcher, until now there has been no research on the phonological awareness of Javanese. Research on the effect of phonological awareness interventions on reading and spelling speed in children's literacy skills. A psychological approach is needed in language, if a person experiences problems in remembering and a decreased awareness of language will result in a psychological stress condition that has impact on a person's mental disorders, stress is a condition of a person's reaction both physically and emotionally (mental/psychologically) when there is a change in the environment which requires someone to adjust $12,13,14,15,16,17,18$. The results showed that phonological awareness intervention was effective in the process of reading and spelling words ${ }^{19}$. Another relevant research is research on the development and relationship between basic metalinguistic skills and word reading skills in Arabic with his research showing that although differences in phonological awareness of each student can be eliminated, morphological awareness and reading skills persist during the junior high school years and on. This research differs in its focus and locus, namely on the development of awareness of Arabic ${ }^{20}$. Another study was a study on the relationship between oral phonological awareness and reading ability of the deaf group, showing the result that learning to read needs to rely on basic language skills and phonological processing 21 . Based on some of the relevant previous studies above, it can be concluded that research is different from this research. This study focused on the level of phonological awareness of ESTE (Elementary School Teacher Education) students in general who are also candidates for Javanese language teachers in elementary schools.

\section{METHOD}

This study used a descriptive qualitative approach. The data of this research were in the form of linguistic units in the form of words, syllables, onset, rhythm, and Javanese phonemes that appear in the learning process of Javanese language for Elementary School Teacher Education students in semester 5 of PGRI Madiun University in the academic year 2020/2021. The data was collected using observation and documentation in the form of student work papers during the Javanese language learning lecture in elementary schools. Data analysis was performed by using the contrastive technique with inductive stage 
22.The stages were selecting data, namely collecting data in the form of words, syllables, onset, rhythm, and phonemes of the Javanese language which are part of phonological awareness; identifying errors, namely identifying errors to determine the level of awareness of Javanese phonology; classifying errors; qualifying error to measure the level of error which then measures the level of phonological awareness; analyzing the source of error, namely analyzing the source of the error; and remediating for errors, which is doing remedial to eliminate the error rate of 22,23 .

\section{RESULT}

This study aimed to determine the level of awareness of Javanese phonology in PGRI Madiun University students, Elementary School Teacher Education study program in semester 5 who were taking Javanese Language Learning courses in elementary schools. The level of phonological awareness can be seen based on the lingual form or the form of written language.

The awareness of lingual phonology of written variety in Javanese language can be seen from the responsiveness of students in placing when they are in the orthographic area and when they are in the phonological area. The data on the ortho-phonological confusion of Elementary School Teacher Education students as future Javanese language teacher candidates in elementary schools can be seen based on their assignments in writing words containing vowels and consonants as described below.

\section{Writing Vowels (Aksara Swara)}

The vowels in Javanese language are 6 letters (a, é, e, i, o, u), while the vowels in Indonesian language are 5 letters (a, e, i, o, u ). In Javanese language, there is aksara swara jejeg and aksara swara miring. Each vowel in the language has swara jejeg and swara miring which is different, however the writing in Latin script remains the same. This has led to confusion in the writing of vowels in Javanese, as shown in the data below.

\section{Writing Vowel /a/}

In the orthographic system, writing jejeg and miring characters are the same, there is no special sign to distinguish the two. The vowels /a/ jejeg and miring are both written/a/, but with a different pronunciation. The letter /a/ jejeg is pronounced [ $\mathrm{J}]$, and /a/ miring is pronounced [a]. This phoneme [3] is considered the same as the letter /o/ in Latin writing so that many write /opo/ instead of /apa/. This is also seen in the following Figure 1.

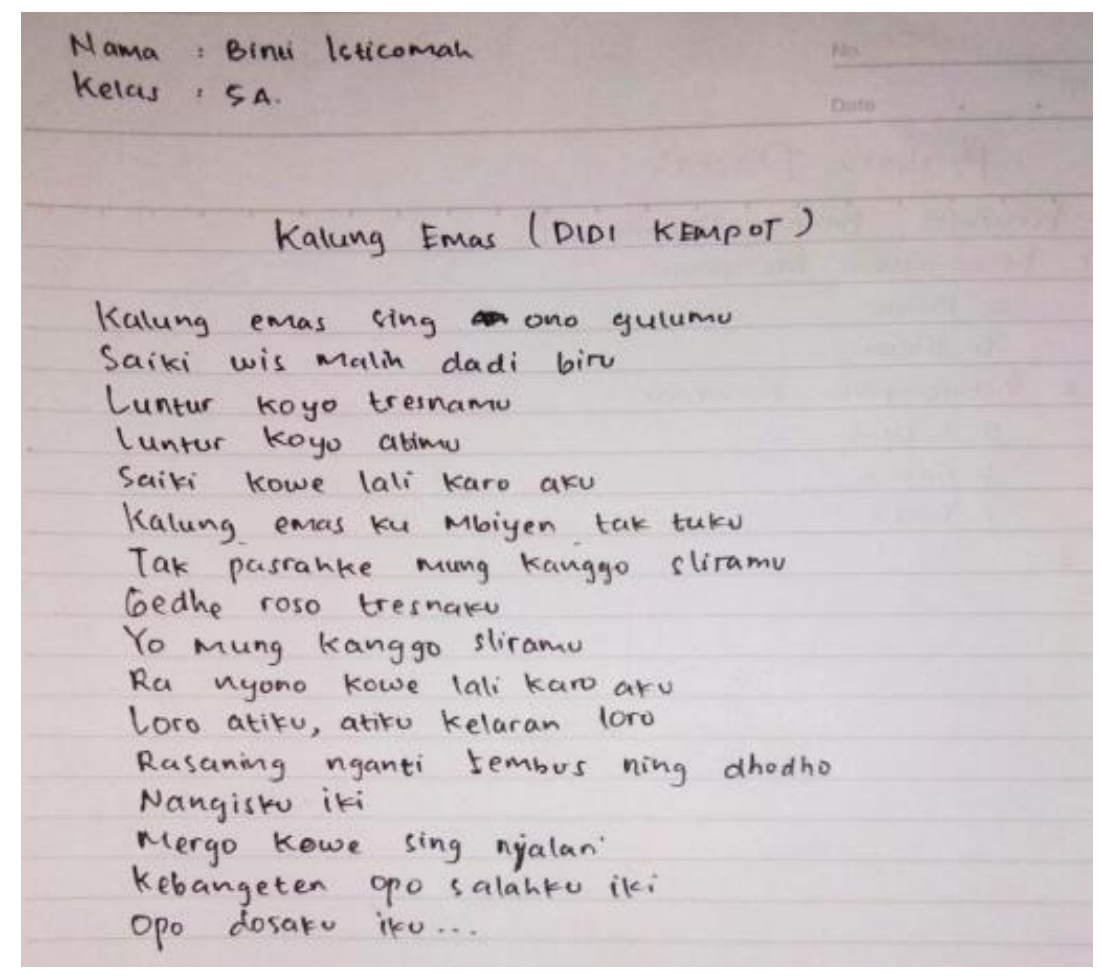

Figure 1 
From the data above, it appears that the writing of words with open syllables containing the letter /a/ is not correct. Starting from the words /ono/, /koyo/, /roso/, /loro/, /dhodho/, /mergo/, and /opo/ which should be written /ana/, /kaya/, /rasa/, /lara/, /dhadha/, /merga/, and /apa/. The number of words in Javanese language that are read not in accordance with the writing triggers this confusion.

\section{Writing Vowel /i/}

Almost the same as writing vowels /a/, in Latin letters the writing of /i/ jejeg is the same as /i/ miring, the difference is in the pronunciation. The letter /i/ jejeg is read like the letter [i] in general, but /i/ miring is read like the letter [e]. This is what makes a writing error in student assignments as shown in Figure. 2 below.

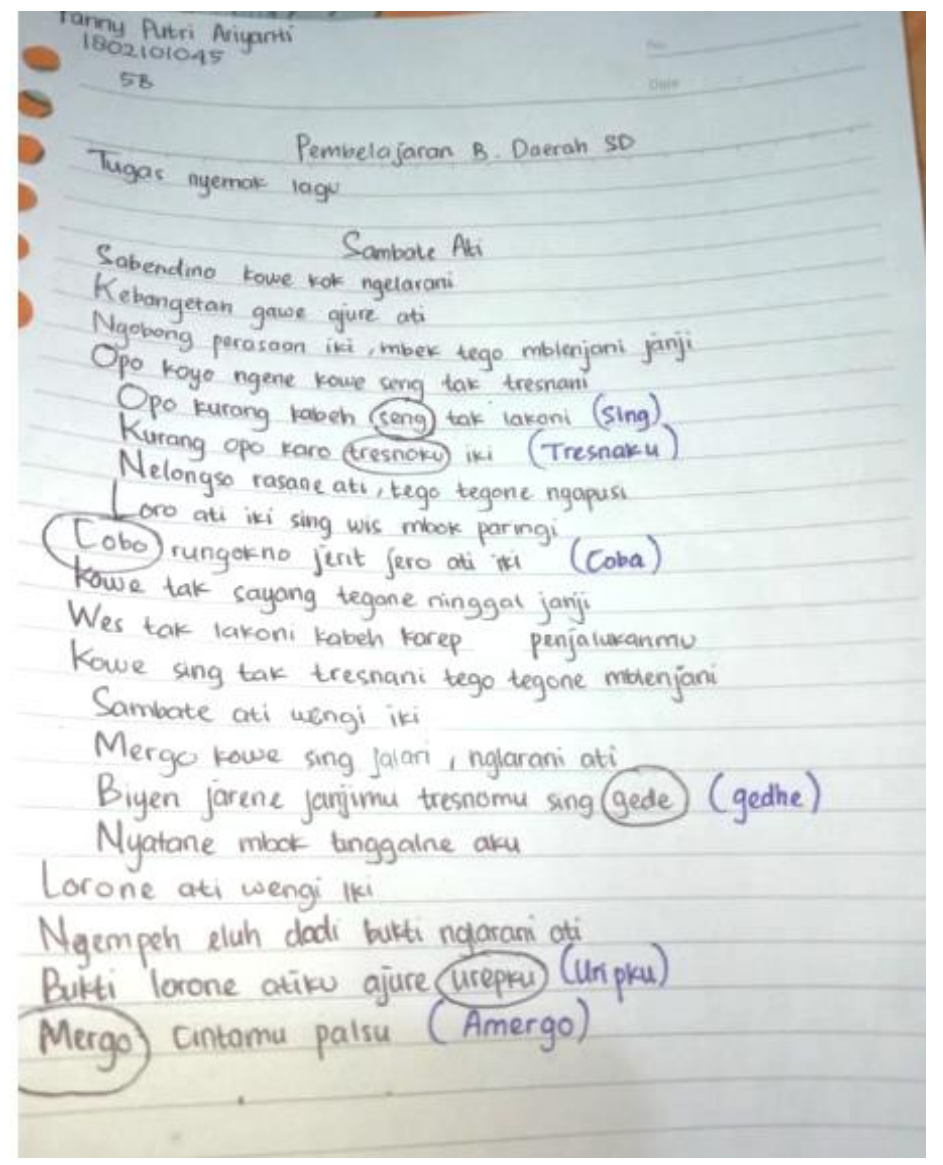

Figure 2

From the data above, it can be seen that the writing of words with closed syllables containing the letter /i/ has been corrected by the students, such as words /seng/ and /urepku/ which should be written /sing/ and /uripku/. If the word /seng/ is read without knowing the context of the sentence, it will be read [seng] which means 'a kind of element or mixture used for coating iron'. This of course adds to the line of words in Javanese that are read inconsistent with the writing that triggers the confusion.

\section{Writing Vowel /u/}

Writing vowels $/ \mathrm{u} /$ is often confused, namely $/ \mathrm{u} /$ miring where the writing is still $/ \mathrm{u} /$ but reads [o]. that difference makes students confused to write / $\mathrm{u} /$ miring. This can be seen in Figure 3 below. 


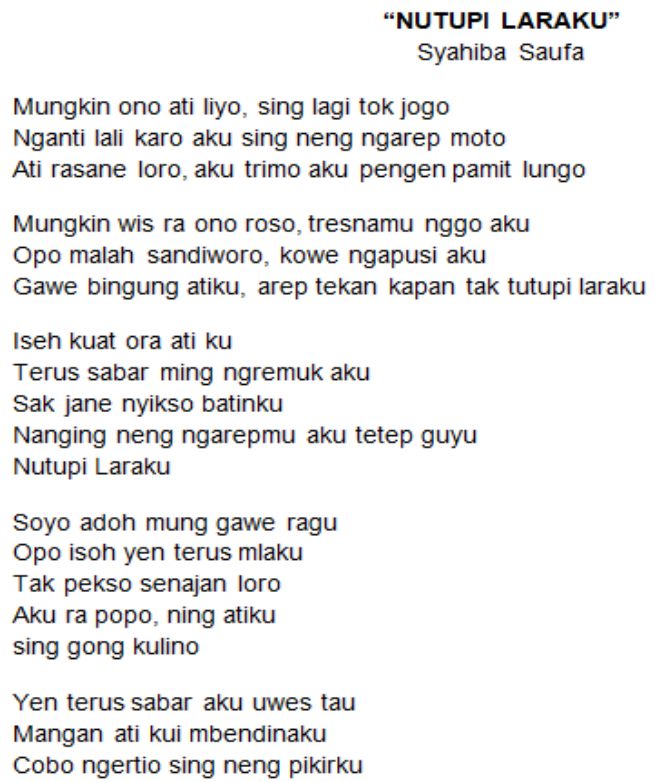

\section{Figure 3}

Based on the data above, the word /gong/ which means ugung 'not yet', and should be written /gung/ instead of /gong/. This is of course has different meaning when reading [gong] which means part of a Javanese gamelan instrument.

\section{Writing Consonant (Aksara Sigeg)}

Javanese language consonants are twenty letters (b, c, d, f, g, h, j, k, l, m, n, p, q, r, s, t, v, w, y, z), while Indonesian language uses twenty-one consonants ( b, c, d, f, g, h, j, k, l, m, n, p, q, r, s, t, v, w, x, y, z). Javanese language uses six combinations of consonants (dh, kh, ng, ny, sy, th), while Indonesian language uses four consonant-letter combinations (kh, ng, ny, sy). Writing consonants in Javanese language where errors often occur are the letters $/ \mathrm{dh} /, / \mathrm{d} /, / \mathrm{th} /$, and $/ \mathrm{t} / \mathrm{both}$ at the beginning and in the middle of words, as well as the letters $/ \mathrm{k} /$ and $/ \mathrm{g} /$ which are at the end of the word.

\section{Writing words containing the letter $/ \mathrm{dh} /$}

Number of words in Javanese language that are lifted from Indonesian language makes students confused about writing them in Javanese, such as in the words pendhidhikan, methodhe, medhia, and so on. If students are confused in writing loanwords from Indonesian language, even the original words from Javanese language, as in Figure 4. below.

\begin{tabular}{|l|l|l|}
\hline 1. pandhawa & 1. pandawa & 1. pandhawa \\
2. dahar & 2. dahar & 2. dhahar \\
3. dhurwur & 3. dhuwur & 3. durwur \\
4. dewe & 4. dheive & 4. dewe \\
5. pandawa & & \\
6. dhahar & & \\
7. durvur & & \\
8. dhewe & & \\
\hline
\end{tabular}

Figure 4

The results of the students' work above were the task of distinguishing between words containing the letter /dh/, the middle column is the wrong word group and the left column is the group of words that the student thought was correct. Based on the data above, it appeared that students could not distinguish between the use of the letter / dh/ correctly. There were different answer choices, namely 2 words from above were correct, but not the case for the next 2 words. The inconsistency of students in applying the orthographic system is influenced by the sound system or phonology. The large number of 
words in Indonesian language that contain the letter /dh/ causes current students begin to hardly recognize words containing the letter $/ \mathrm{d} /$.

\section{Writing words containing the letter /th/}

Students' confusion in writing Javanese words containing the letter /th/ is because teenagers rarely hear words in Indonesian language that contain the letter /th/ causing students begin to hardly recognize words containing the letter /th/. This is shown in Figure 5. below.

\begin{tabular}{|l|l|l|}
\hline 1.tiwul & 1. tiwul & 1. thiwul \\
2. nyathet & 2. nyatet & 2. nyathet \\
3. setitik & 3. sethithilk & 3. setitik \\
4. thengul & 4. thengu & 4. tengu \\
5.thiiwul & & \\
6. nyatet & & \\
7. sethithik & & \\
8. tengul & & \\
\hline
\end{tabular}

Figure 5

The results of the student work above were the task of distinguishing between words containing the letter /th/, the middle column is the wrong word group and the left column is a group of words that the student thinks is correct. Based on the data above, it appeared that students could not distinguish between the use of the letter /th/ correctly. There were different answer choices, namely words /setitik/ which students felt were correct. This is because of the word /titik/ in Indonesian. That was why students choose them in groups of words whose writing was correct.

\section{Writing words containing the letter $/ \mathrm{g} /$ at the end}

Students' confusion in writing Javanese words containing the letter $/ \mathrm{g} /$ is because the teenagers rarely hear words in Indonesian language that contain the letter /g/ causes students begin to hardly recognize words containing the letter $/ \mathrm{g} /$. This is shown in Figure 6 below.

\begin{tabular}{|l|l|l|}
\hline 1. cocok & 1. $\operatorname{cocog}$ & 1. cocok \\
2. pileg & 2. pileg & 2. pilek \\
3. warek & 3. warek & 3. wareg \\
4. ketig & 4. ketig & 4. ketilk \\
5. cocog & & \\
6. pillek & & \\
7. ketik & & \\
8. cocok & & \\
\hline
\end{tabular}

Figure 6

Based on data above showed that students were still confused in distinguishing words ending in the letters $/ \mathrm{k} /$ and $/ \mathrm{g} /$. This is proven from the group of correct answers, there was only one correct word, namely the word /wareg/. If only students were able to apply the pronunciation of words that ended in /g/ with words that ended in / $\mathrm{k} /$ in Indonesian language, then the confusion would not occur. The large number of words in Javanese language which are almost the same in pronunciation as the words in Indonesian language have confused. However, if students could find out the word /pileg/ which 
means legislative choice, the pronunciation is the same as the word /pileg/ means 'flu' in Javanese language, of course the word /pilek/ will not be chosen.

\section{Writing words containing the letter /d/ at the end.}

Students' confusion in writing Javanese words containing the letter /d/ at the end was due to the fact that young people rarely hear words in Indonesian that contain the letter /d/. Only a small number of words that contain /d/ at the end, such as the word /murid/ which still appear frequently. In Javanese language, many words contain the letter /d/ at the end, as in Figure 7 below.

\begin{tabular}{|l|l|l|}
\hline Tembung & kliru & pener \\
\hline 1. reged & 1. reget & 1. reged \\
2. saget & 2. ngeliwed & 2. ngeliwet \\
3. ngeliwed & 3. welud & 3. welut \\
4. welut & 4. saged & 4. saget \\
5. reged & & \\
6. saged & & \\
7. ngeliivet & & \\
8. welud & & \\
\hline
\end{tabular}

Figure 7

The data above showed that students were still confused in distinguishing words ending in the letters $/ \mathrm{d} /$ and $/ \mathrm{t} /$ because their pronunciation is almost the same. This is proven from the group of correct answers, there are many words are true but some of them are still wrong, namely the word /saget/ which should be written /saged/.

\section{Writing words containing the letter $/ y /$ in the middle}

Phoneme [y] which should be exist between the two vowels in Javanese language should be written with the letter /y/, as in the word /reog/, /kuliah/, /siang/, which should be written /reyog/, /kuliyah/, and /siyang/. In the data collected from student assignments there was confusion, namely the word /sio/ which should be written /siya/ as in Figure 8 below.

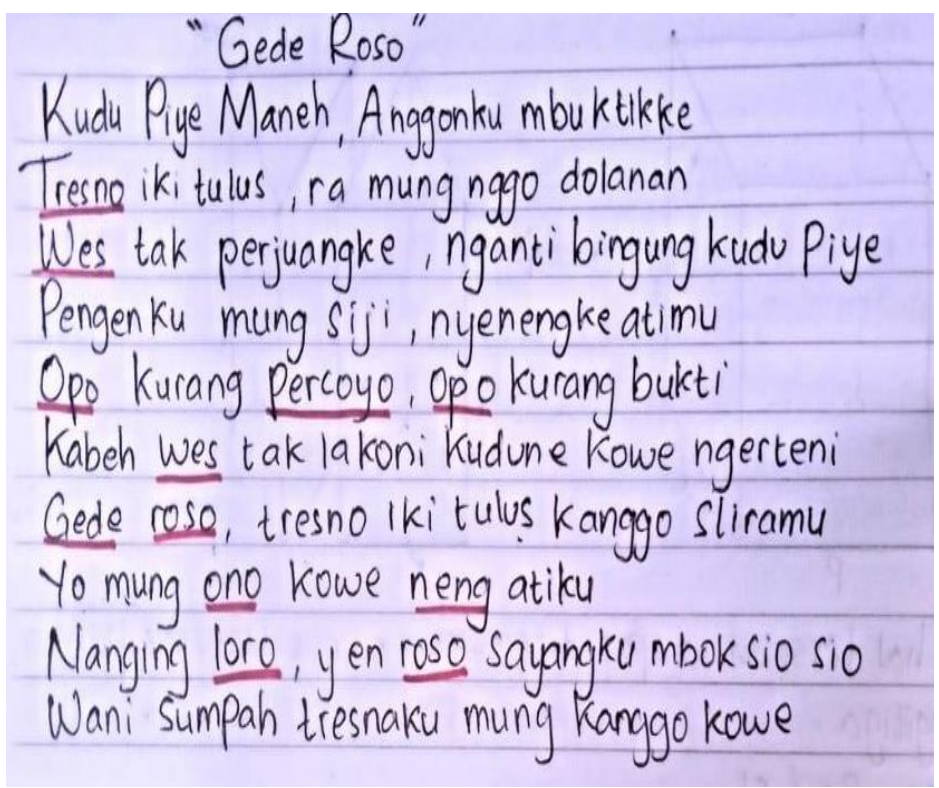

Figure 8 
Based on the data above, the word /sio-sio/ 'sia-sia' which means 'hopeless' is written without the letter / $y /$ in the middle. This is because in Indonesian language, the word /sia-sia/ is written without the letter $/ y /$. Thats why confused occured, and at the end students choose like an ortograph in Indonesian which is without the letter /y/. Based on these data, it can be concluded that speech uses [y] is speech that is affected by the spelling system and speech that does not use [y] is natural speech (not affected by the orthographic system). This is very influential when it comes to writing Javanese characters, because in writing Javanese characters, what is written is what is spoken. If in writing /Lia/ but the pronunciation [Liya], then in writing Javanese characters you also have to use character yes, not ha.

\section{Writing words containing the letter / $\mathrm{w} /$ in the middle}

It had similar case with the phoneme [y], the phoneme [w] is also considered unnecessary to be written in the Javanese orthographic system. Based on the data collected from student assignments there was confusion, namely the word /kuat/ which should be written /kuwat/ as in Figure 9 below.

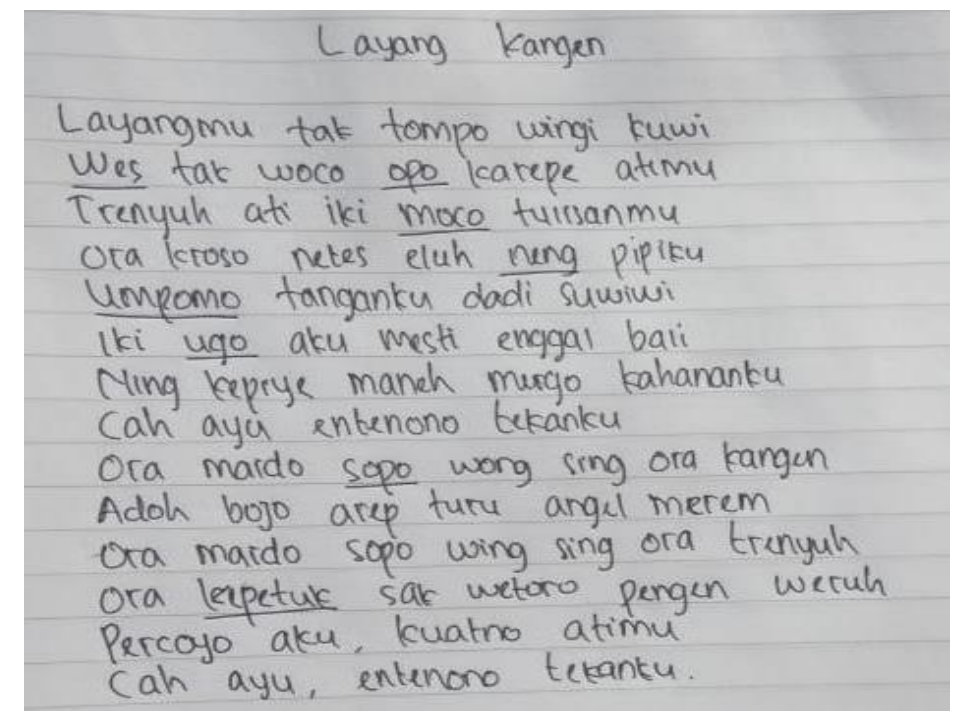

Figure 9

Based on the data above, word /kuatno/ means 'strengthen' is written without the letter / $\mathrm{w} / \mathrm{in}$ the middle. This is because in Indonesian language, the word /kuat/ is written without the letter /w/. That was what confused to occur, and at the end the students choose something like orthographics in Indonesian language without the letter /w/. Based on these data, it can be concluded that speech uses [w] is speech that is affected by the spelling system and speech that does not use [w] is natural (not affected by the orthographic system). This is very influential when it comes to writing Javanese characters, because in writing Javanese characters, what is written is what is spoken. If in writing /Lia/ but the pronunciation [kuwat], then in writing Javanese characters you must also use wa character.

\section{DISCUSSION}

The awareness of written lingual phonology in Javanese language is the student's ability in mastering the orthographic system and understanding the concept of phonology ${ }^{24,25}$. The similarity between graphic signs and phonetic symbols in the orthographic system of the Javanese language in Latin letters, like the two sides of a coin, on a hand is an advantage, but on the other hand is a disadvantage. The advantage is that because of the many similarities, people can easily pronounce Javanese words without even a background in phonological knowledge. Meanwhile, the disadvantage is that a person is easily dragged into an obscure area, it is when they are in the phonological area and when they are in the orthographic $\operatorname{area}^{26,27}$

In the orthographic area of Javanese language, there are two types of characters, namely Latin characters and Javanese characters or aksara Jawa legena. The two types of characters in Javanese language certainly influence each other in terms of orthography. The existence of this influence certainly confused writing spoken Javanese. Confusion in writing spoken language or called ortho-phonological confusion can occur because of the uncertainty of standard Javanese pronunciation. Until now, there are still many Javanese language users, both laymen and educated circles who still confuse the phonological 
system and the orthographic system. If this case occurs in ordinary people, it may not have much of an impact, but if it occurs in the smart and intellectuals like Elementary School Teacher Education students who later teach Javanese language at the initial level, namely in elementary school, it will certainly have a wide impact.

Here are some facts about the Javanese phoneme system.

a. Javanese language does not recognize [a] at the final position, except for the word ora [ora] means 'no' which is still written and read as ora [ora] not oro or ara.

b. The phoneme [ग] in the final position in Javanese corresponds to the phoneme [a] in Indonesian:

[วpग] vs. [apa] means 'what'

[gulJ] vs. [gula] means 'sugar'

[rups] vs. [rupa] means 'appearance'

c. Javanese language recognizes phonemes $/ \mathrm{th} /, / \mathrm{dh} /$, and $/ ə /$ :

[d]: /wedi/ [wədi] means 'fear' vs [d]]: /wedhi/ [wədi] means 'sand'

[t]: /tutuk/ [tutU'] means 'mouth' vs [ț]: /thuthuk/ [țuțU'] means 'hit'

[ə]: commotion [gəgər] means 'back' vs [ع]: geger [geger] means 'lousy'.

d. Javanese language does not recognize diphthongs.

e. Javanese language always adds a nasal vocoid in front of a place name starting with a voiced contoid:

/Bogor/ [mbJgrr] 'Bogor'

/Jombang/ [ñjomban] 'Jombang'

/Gombong/ [ngəmbə⿱] 'Gombong'

/Month/ [mbulan] 'Bulan'

The factor that causes ortho-phonological confusion is the presence of linguistic factors and nonlinguistic factors. Linguistic factors in the form of differences in phonological systems and orthographic systems in one language or between languages that are not understood by language users. Also, Javanese speakers ignore or do not understand the differences between the phonological system and the orthographic system. This indifference is very common because, since elementary school, the language learning model has been led to a traditional model where writing equals language. In there, language lessons are identified with reading and writing lessons. Listening and Speaking, which are the essence of language learning, are neglected. Starting from this point then emerge two kinds of language, namely spoken language and written language. This kind of thing continues to understanding at the next level. Even Javanese linguists have been trapped by the confusion between spoken language (the language in its true meaning) and written language (the embodiment of language with graphic media), for example in Javanese language textbooks in schools.

The nonlinguistic factors that influence are such as the style of speech of students who like to follow figures who write their names with 'o'. For a paternalistic society, imitating a respected figure is a habit that is difficult to break. Even if they understood the orthographic rules and the phonological rules, the confusion in writing would still occur and continue. Furthermore, writing with the letter ' $\mathrm{o}$ ' for names that are lifted from Javanese names is also caused by the intention of directing the reader to the pronunciation [ग] which ethnophonetically characterizes the person with the name as truly Indonesian from Javanese ethnicity. If it is written in the letter ' $a$ ', it has the potential to be pronounced [a] so that the person with the name will be mistaken for Sundanese or other non-Javanese ethnicities ${ }^{28,29}$. This is in line with what other studies have shown that the use of Indonesian names derived from Javanese names which use the low-back-round vocoid [pada] in the final position orthographically must be written with the letter ' $a$ ' because the sound is an allophon of the phoneme $/ a /{ }^{30}$.

In spelling using the phonemic system, letters or graphemes are representations of phonemes. In this case, the letter ' $a$ ' is a representation of the phoneme /a/ not a representation of the vocoid [?], which in this case is not a phoneme. So, Javanese names such as Surana, Suparta Brata, etc. should be written with the letter ' $a$ '. In the case of the pronunciation of the names, the pronunciation is still used in the original language, because there is no Indonesianization of the names as previously stated. Thus the pronunciation is still [SurJn]], [suparts brot]], even though it is written as 'Surana', 'Suparta Brata'. Some speakers are influenced by the orthographic system so that they pronounce [surana], [suparta brata]. This can deceive or mislead the listener because such pronunciations sound like names from a nonJavanese ethnicity. At other times the owner of the name will feel strange when his/her name is called with a pronunciation like that. This further adds to confusion learners, because in writing which still used 'o' will mislead students because it'll write 'taling tarung', when it should be using aksara legena without any sandhangan ${ }^{31}$. 


\section{CONCLUSION}

Based on the analysis, it can be concluded that the phonology awareness of Javanese language teacher candidates for elementary school of Javanese language teachers is still low. Lots of mistakes in writing words. This occurs because of the confusion between phono-orthological and ortho-phonological confusion which confused students to determine where to place themselves. This result is important to follow up considering that phonological awareness of elementary school teacher candidates has an effect on the level of mastery of other language material, and can certainly have an effect on the learning outcomes of elementary school students' Javanese language. The factors causing ortho-phonological confusion are the presence of linguistic factors and nonlinguistic factors.

\section{REFERENCES}

Şeref, İ., \& Varışoğlu, B. The investigation into prospective teachers' Turkish metalinguistic awareness. Dil ve Dilbilimi Çalışmaları Dergisi, 16(2), 959-977. 2020

Suhron, M. "Asuhan keperawatan jiwa konsep self esteem/Care of Mental Nursing The concept of selfesteem". Jakarta: Mitra Wacana Media; 2017

Suhron M., Asuhan keperawatan konsep diri: Self esteem/ Self-concept nursing care: Self esteem (Selfesteem nursing care), "Publisher, Ponorogo: Unmuh Ponorogo Press. 2016

Bolitho, R., et al. Ten questions about language awareness. ELT Journal, 57(3), 251-259. 2003.

Lier, VL. Inside the Classroom: Learning Processes and Teaching Procedures. Applied Language Learning, 2(1), 29-68. 1991.

Mendoza CH. Critical Language Awareness (CLA) forSpanish Heritage Language Programs: Implementing a Complete Curriculum, InternationalMultilingual Research Journal, 12:2, 65-79, 2018

Lindah K,et al.The intersection of language ideologies and language awareness among in-service teachers of emergent bilinguals. Journal of Immersion and Content-Based Language Education, Vol7(1).; p. $61-87.2019$

Mintowati, et al. Education Qualification for Professional Development of Javanese Language Teachers in East Java: Case Study. Advances in Social Science, Education and Humanities Research, 2nd Social Sciences, Humanities, and Education Conference (SoSHEC 2018)vol 222. 2018

Blachman, BA.. Phonological awareness. 2000

Stoel-Gammon, C. Relationships between lexical and phonological development in young children. Journal of Child Language, 38(1), 1.2011

Robbins, C., et al Reading storybooks to kindergartners helps them learn new vocabulary words. Journal of Educational Psychology, 86(1), 54. 1994

Suhron, M, A Yusuf, R Subarniati. Assessment of Stress Reactions and Identification of Family Experiences in Primary Care Post Restrain Schizophrenia in East Java Indonesia. Mix Method: Sequential Explanatory. Indian Journal of Public Health Research \& Development. 2018;10(12):1849-1854.

Yusuf, Ah., Rika, S., Suhron, M., "Assessment of the Kempe Family Stress Inventory in self-care postrestrain schizophrenia," International Journal of Public Health Science (IJPHS), vol. 8, no. 2, pp. 55 59, 2019

Suhron M, A Yusuf, R Subarniati, F Amir, Z Zainiyah. How does forgiveness therapy versus emotionfocused therapy reduce violent behavior schizophrenia post restrain at East Java, Indonesia? 2020. International Journal of Public Health Science (IJPHS) 9 (4), 214-219

Suhron, F Amir. Reduce violent behavior schizophrenia: A new approach using LT (Laughing therapy) and DRT (Deep relaxation therapy). Indian Journal of Public Health Research \& Development. 2018:9(8):1518-1523

Suhron, M. Model of Potential Strengthening and Family Roles in Improving Family Members for ODGJ Adaptability http://conference.unair.ac.id/index.php/isoph/isoph/paper/view/1147. Publication Name : proceeding of The 2nd International Symposium of Public Health. 2018;1(1):344-354.

Yusuf Ah, S Sulaihah, HE Nihayati, M Suhron. The Role Of Families Caring For People With Mental Disorders Through Family Resilience At East Java, Indonesia: Structural Equation Modeling Analysis. Systematic Reviews in Pharmacy. 2020.11 (9), 52-59

Suhron M, zainiyah z., How Were Stress Family and INSR (Insulin Receptor) Expression in Polycystic Ovary Syndrome (PCOS) Insulin Resistant in Madurese Tribe?: Indonesia. Systematic Reviews in Pharmacy. Vol 12(1), pp. 170-175. 2020

Bruck, M., \& Genesee, F. Phonological awareness in young second language learners. Journal of Child Language, 22(2), 307-324. 1995. https://doi.org/10.1017/S0305000900009806

Anthony, JL., \& Francis, DJ. Development of phonological awareness. Current Directions in Psychological 
Science, 14(5), 255-259.2005

Vander SC., \& Reybroeck, MV. Phonological awareness and rapid automatized naming are independent phonological competencies with specific impacts on word reading and spelling: an intervention study. Frontiers in Psychology, 9, (1)pp 320. 2018

Schiff, R., \& Saiegh-HE. (2018). Development and relationships between phonological awareness, morphological awareness and word reading in spoken and standard Arabic. Frontiers in Psychology, 9, 356.

Lederberg, AR., et al. Modality and interrelations among language, reading, spoken phonological awareness, and fingerspelling. The Journal of Deaf Studies and Deaf Education, 24(4), 408-423. 2019.

Allen, JPB., \& Corder, SP. Techniques in applied linguistics (Vol. 3). Oxford University Press. 1974

Herlina Jusuf, Muhammad Sakti, Ismail Husein, Marischa Elveny, Rahmad Syah, Syahrul Tuba. "Modelling Optimally to the Treatment of TB Patients for Increase Medical Knowledge." Systematic Reviews in Pharmacy 11.4 (2020), 742-748. Print. doi:10.31838/srp.2020.4.107

Syah Rahmad, M K M Nasution, Ismail Husein, Marischa Elveny, "Optimization Tree Based Inference to Customer Behaviors in Dynamic Control System", International Journal of Advanced Science and Technology, pp. 1102 - 1109,2020.

Husein Ismail, Rahmad Syah, "Model of Increasing Experiences Mathematics Learning with Group Method Project", International Journal of Advanced Science and Technology, pp. 1133-1138, 2020.

Syah Rahmad, Mahyuddin K.M Nasution, Ismail Husein, "Dynamic Control Financial Supervision (OJK) for Growth Customer Behavior using KYC System", International Journal of Advanced Science and Technology, pp. 1110 - 1119, 2020

Jessica SCet al. Explaining phonology and reading in adult learners: Introducing prosodic awareness and executive functions to reading ability. Journal of Research in Reading. Vol 41(1). pp 42-57.2018

FauziAI et al. Dialect and Identity: A Case Study of Javanese Use in WhatsApp and Line. IOP Conference Series: Earth and Environmental Science, Volume 175, International Conference on Industrial Technology for Sustainable Development (ICon-ITSD). 25-26 October 2017, 2017.

Pytlyk C. Are orthographic effects language specific? The influence of second language orthography on second language phoneme awareness. Applied Psycholinguistics, Vol 38(2), pp. 233 - 262. 2017

Errington JJ. Continuity and Change in Indonesian Language Development. The Journal of Asian Studies. Vol. 45(2)pp. 329-353. 1986

Kartikasari E. The Lexical And Phonological Differences of Javanese In Banyuwangi And Surabaya.International Conference on Science, Technology \& Environment (ICoSTE). 2019

Soeparno. Kerancuan fono-ortografis dan orto-fonologis bahasa indonesia ragam lisan dan tulis. DIKSI, $7(12), 204-219.2005$

Prat, CS., et al. Relating Natural Language Aptitude to Individual Differences in Learning Programming Languages. Sci Rep 10;3817. 2020 